\title{
Tsunami Zonal Marking Application using Google Application Protocol Interface
}

\author{
Ni Luh Ayu Kartika Yuniastari Sarja, I Wayan Budi Sentana, Nyoman Ayu Nila Dewi
}

\begin{abstract}
Tsunami Zonal Marking application is part of a project aims to create an integrated application to conduct tsunami evacuation and mitigation process. This integrated application called INTERGIS consists of three main parts or modules, which are back-end, front-end and interoperability modules. Tsunami zonal marking back-end module is a web-based application used by authoritative users, such as Regional Disaster Management Agency and Disaster Operational Control Centre officer, to marking the tsunami impacted area as well as to pointing the assembly safe point in digital maps application. While the front-end module is an Android based application that can assist the user to reach the nearest safe assembly point when the tsunami disaster occurs. This application activated when it is triggered by BMKG's INATEWS tsunami early warning system. The Interoperability module is part of application that organize the data connection to BMKG's INATEWS and Google API web services. This paper explores more on back-end module that built on CodeIgniter PHP framework. This application has been developed and has successfully mapped tsunami zones in several areas of Bali. This app utilizes google Application Programming Interface (API) and can be used by SAR units from each district. The tsunami zone data and the assembly point will be supplied by the Regional Disaster Management Agency (BPBD) of each district.
\end{abstract}

\section{Index Terms:}

\section{INTRODUCTION}

Tsunamis are waves caused by the movement of large volumes of water in the deep ocean or lake, due to earthquakes, landslides, underwater explosions, or meteorite collisions in the water [1]. At the coastline, the waves formed can reach tens of meters high and cause very severe damage. One of the greatest tsunamis was the 2004 Indian Ocean earthquake that affected Indonesia, India, Thailand and other countries with 225,000 deaths [1]. In Indonesia, the tsunami caused 105,262 people died in Aceh and its surrounding areas [2].

Disaster mitigations can be used to reduce the impact of tsunami catastrophe. Tsunami disaster mitigation is including the preparation of Tsunami Early Warning System (TEWS) that can predict the tsunami occurrence. To support this system, various methods are developed to decide whether a seafloor movement can lead to a tsunami or not. As performed by [3] which undertook measurements of

Revised Manuscript Received on April 25, 2019.

Ni Luh Ayu Kartika Yuniastari Sarja, Department of Information System, STMIK STIKOM Bali, Jl. Raya Puputan No.86, Renon, Denpasar, Indonesia.

I Wayan Budi Sentana, Department of Information Systems, Bali State Polytechnic, Jl. Raya Bukit Jimbaran, Badung, Bali, Indonesia. STIKOM Bali, Jl. Raya Puputan No.86, Renon, Denpasar, Indonesia.
Nyoman Ayu Nila Dewi, Department of Information System, STMIK

submarine water pressure and posted the results via SAR satellites, or research conducted by [4] which also undertook measurements of pressure beneath the surface of the seafloor. Another way of detecting a tsunami is to perform wave height measurements as done by [5]. Various algorithms were also developed to accelerate computing process of tsunami occurrences, as did by [6]. [7] has even invented high-wave detection equipment despite being in a black out condition, by utilizing satellite.

Tsunami alerts will be disseminated to several government agencies. In Indonesia, tsunami early warning systems is coordinated by Meteorology, Climatology and Geophysics Agency (BMKG). BMKG has several dissemination channels to warn the emergence of tsunamis, such as through SMS gateways, satellite channels, Telephone, Fax and web services, which are linked to several government institutions. Through this path, the Regional Disaster Management Agency (BPBD) will provide a warning to residents by activating the sirens around the coast. But none of the previous project work with the application that can guide residents to reach the nearest safe assembly point. The current tsunami evacuation flow is only a very dangerous directive board and can be misleading to its users. In addition, in Indonesia there are only a few districts that have digital map applications to map tsunami.

Hence, this research developed an integrated application to assist the evacuation process. This application will integrate BMKG alert system, Google Maps API and web-based applications as well as android. The initial phase of development of this integrated system is to create an application that can mark the tsunami affected zone, where this application can be used by BPBD officers in each district. This paper will cover more on the development of mentioned tsunami affected zone marking application.

\section{RELATED WORKS}

The TEWS model has been developed with various media available, such as those conducted by [8], by utilizing social media Twitter, or by utilizing mobile applications as developed by [9]. Indonesia also has a tsunami early warning called Indonesia Tsunami Early Warning System (INATEWS). Developed since 2005, INATEWS is coordinated by BMKG and involves many institutions such as Indonesian Institute of Sciences (LIPI), Indonesian Assessment and Application of Technology Board (BPPT), BPBD, Police Department, several related ministries and representatives of other countries. INATEWS conducts dissemination of tsunami early warning through various channels through SMS, e-mail,

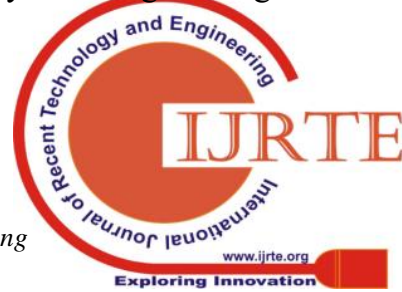


fax, Warning Receiver System (WRS) and Global Telecommunication System (GTS).

In addition to TEWS, another form of tsunami disaster mitigation is developing ad evacuation and educational flow maps and evaluate the effectiveness of TEWS for the community. Some areas already have tsunami evacuation charts, such as those held by [10] and [11]. UNESCO has also issued tsunami evacuation guidance for hotels through [12]. The vertical shelter development guidelines have also been developed by [13]. Vertical shelter became one of the alternative places to gather as it has been widely developed in Padang [14]. Utilization of artificial intelligence for evacuation site selection has also been developed by [2] Community education on tsunamis and the measurement of the effectiveness of TEWS are also an important part of tsunami disaster mitigation, as evidenced by research conducted by [15] and [16].

On the other hand, there have been many map-based applications that have been developed by using google maps Application Programming Interface (API), as done by [17] and [18]. This service can be utilized to create tsunami-based evacuation applications digital maps. This is the background of application development.

\section{RESEARCH METHODOLOGY}

The grand design of this integrated system is shown as in Figure 1, where there are three main parts: mobile application, web-based back-end application and parts used to integrate some required services from third parties. This paper will focus more on the part used by the authoritative user, where the application in this section will be used to mark the tsunami affected zone and assembly point. In addition, this section is used to maintain supporting information such as news data, and donors who participate in supporting this application. In addition, the initial focus of the development of this application also leads to applications used by end-users based on the web. In this section, the user can see the results of mapping of affected zones and assembly points that have been set by trusted users. Authoritative users have a privilege to marking the zone that include into tsunami affected zone and also pointing the point that will use as place of assembly point. Zone marking in this information system using google maps application protocol interface as a basic map as well as the library of marking task.

As with most information systems development, this tsunami zone mapping application follows the stages of Software Development Life Cycle. The cycle includes analysis, design, implementation, and maintenance, where each of these steps will be explained as follows. In addition, Unified Modeling Language (UML) is used in the analysis and design phase of this software development. The steps of information system development are shown in Figure 2.

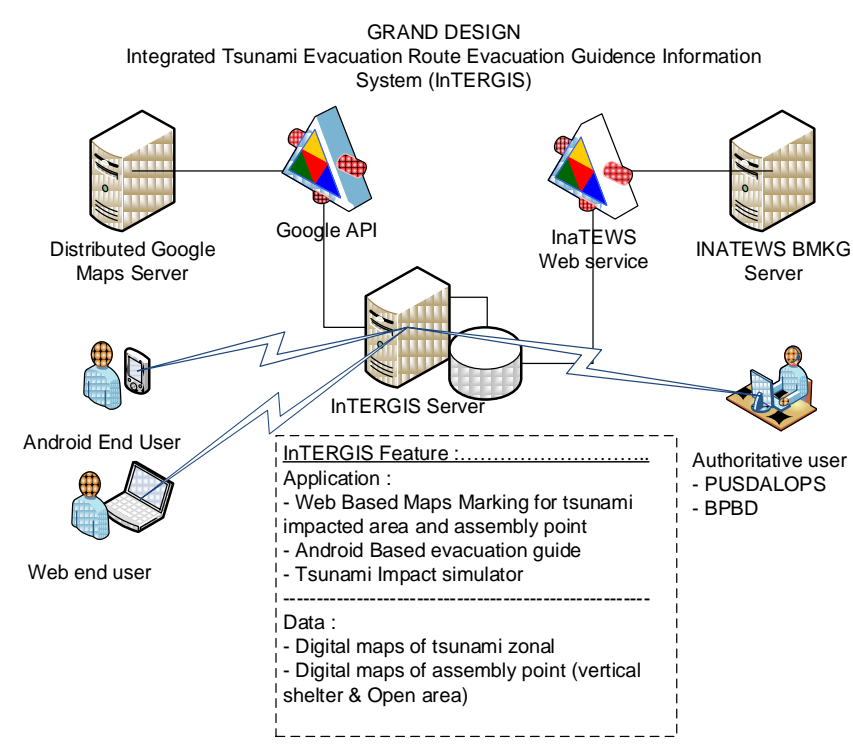

Fig. 1. INTERGIS Framework

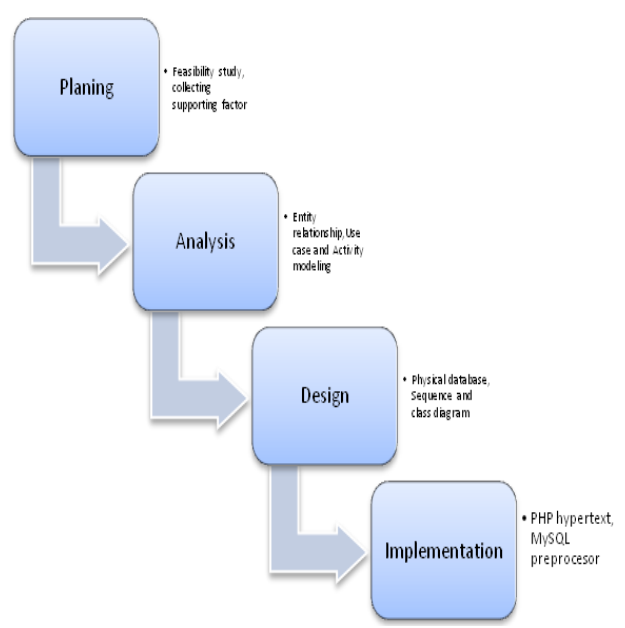

Fig. 2. INTERGIS Information system development cycle

\section{A. Analysis}

The analysis phase is used to obtain all the requirements of this zone marker software. After conducting discussions with BPBD Bali Province, then determined the features that exist in the application with reference to the distribution of work in each district. The number of authoritative users is possible for more than one, wherein each district BPBD is entitled to mark their area, especially those adjacent to the beach. There are two main features: marking the area divided into very dangerous areas, rather dangerous and safe zone. each region will be given overlays with different colors. In addition to the affected zone, a feature that also exists in this application is the procurement of a safe place to gather. The full feature of the tsunami disaster zonal application can be seen in Figure 3. and Table 1 . 


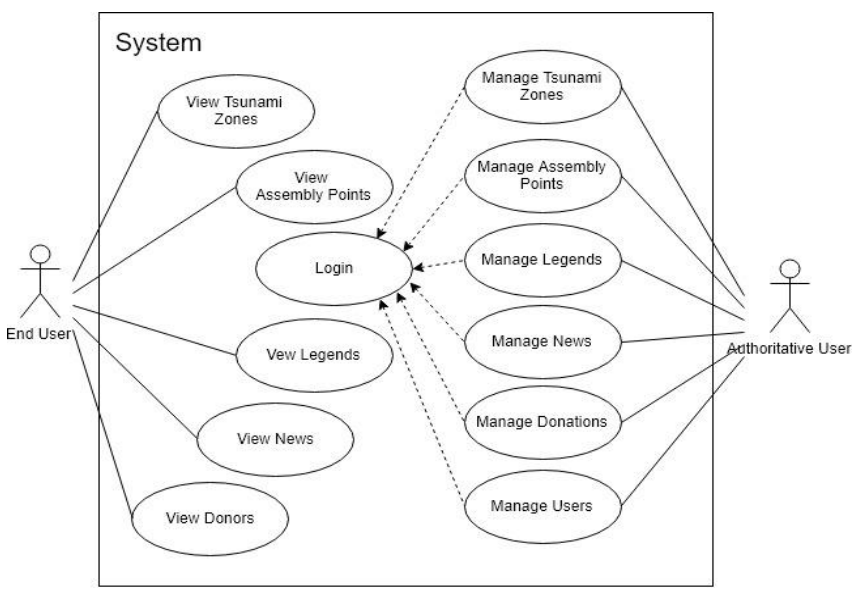

Fig. 3. Use Case Diagram

Use case diagrams are used to describe the needs of the system in general. The system has two types of users with each accessible feature seen as in Figure 3.

Table 1. Application Features

\begin{tabular}{|c|c|c|}
\hline \multirow[t]{2}{*}{ User } & \multicolumn{2}{|r|}{ Application's Feature } \\
\hline & Feature & Description \\
\hline \multirow[t]{6}{*}{$\begin{array}{l}\text { Autoritative } \\
\text { user }\end{array}$} & $\begin{array}{l}\text { Manage } \\
\text { Tsunami } \\
\text { Zone }\end{array}$ & $\begin{array}{l}\text { map/zone marker based on polygon overlay service } \\
\text { trough certain latitude and longitude coordinates }\end{array}$ \\
\hline & $\begin{array}{l}\text { Manage } \\
\text { Assembly } \\
\text { Point }\end{array}$ & $\begin{array}{l}\text { Assembly safe point pointing using google maps } \\
\text { pointing service based on longitude and latitude object }\end{array}$ \\
\hline & $\begin{array}{l}\text { Manage } \\
\text { Legends }\end{array}$ & $\begin{array}{l}\text { Used to create a legend on map, including all } \\
\text { supporting sign on evacuation process }\end{array}$ \\
\hline & Manage News & Used to maintain news thread \\
\hline & $\begin{array}{l}\text { Manage } \\
\text { Donations }\end{array}$ & Used to maintain information related to donor \\
\hline & Manage Users & Used to maintain authoritative users \\
\hline \multirow{6}{*}{ End user } & View & \\
\hline & $\begin{array}{l}\text { Tsunami } \\
\text { zones }\end{array}$ & Used to view tsunami zones \\
\hline & $\begin{array}{l}\text { View } \\
\text { Assembly } \\
\text { Points }\end{array}$ & Use to view safe assembly points \\
\hline & $\begin{array}{l}\text { View } \\
\text { Legends }\end{array}$ & Used to view legends \\
\hline & View News & Used to view news feeds \\
\hline & View Donor & Used to view donor \\
\hline
\end{tabular}

\section{B. Design}

The design phase is used to design the structure of this application. There are two diagrams that are used to help the design process that is class diagram and sequence diagram. Sequence diagrams describe the application flow based on the application structure depicted on the class diagram. Each use case or feature is described in the sequence diagram and its structure. Examples of sequence diagrams that exist in this application development are shown in Figure 4.

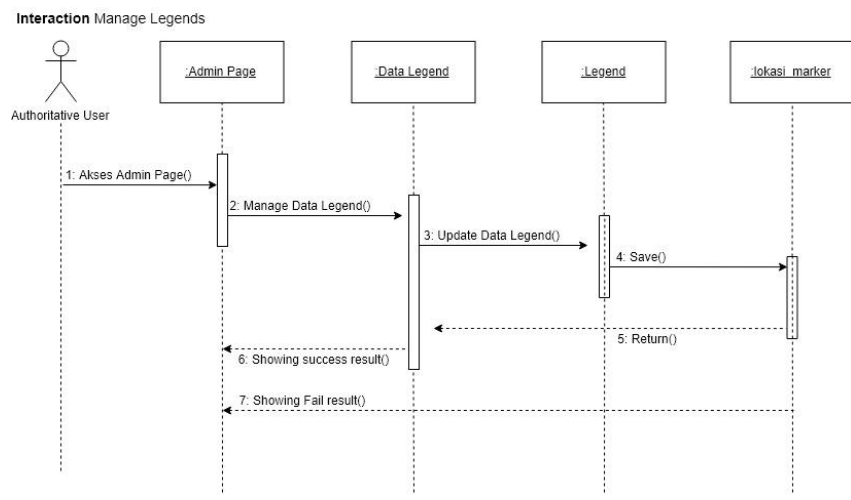

Fig. 4. Sequence Diagram of Manage Legends Feature

\section{Implementation}

The implementation phase is used to translate the design results into applications by utilizing certain programming languages. In this application, the language used is PHP that is packaged in the framework CodeIgniter and MySQL database. CodeIgniter is a powerful PHP framework with a very small footprint, built for developers who need a simple and elegant toolkit to create full-featured web applications[19]. CodeIgniter is loosely based on the popular model-view-controller (MVC) development pattern. While controller classes are a necessary part of development under CodeIgniter, models and views are optional. Codeigniter can be also modified to use Hierarchical Model View Controller (HMVC) which allows developers to maintain modular grouping of Controller, Models and View arranged in a sub-directory format. The access model of CodeIgniter is shown on Figure 5.

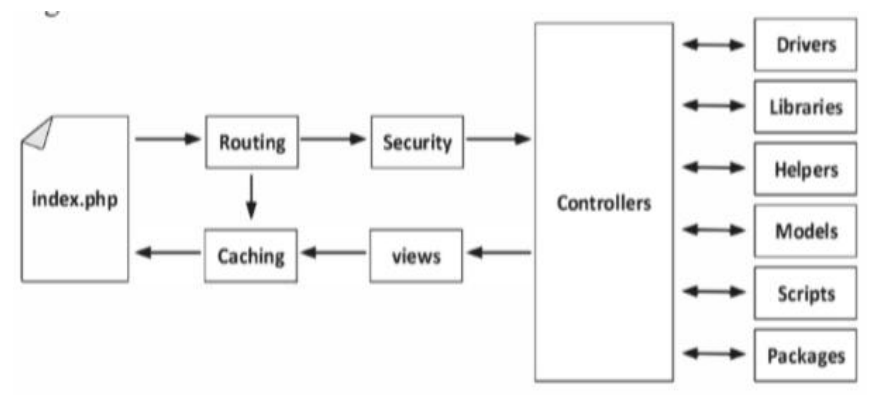

Fig. 5. CodeIgniter Framework

"Index.php" acts as the leading controller and initializes the necessary resources to run Code Igniter. The router checks the HTTP request to determine what to do. If the cache file exists, it will be displayed directly, by passing the system's normal execution. Before loading the controller, the HTTP request will check what the user submits and filter for security. The controller loads models, core libraries, plugins, helper, and other resources to process a specific request. 


\section{PROJECT OVERVIEW}

This application has been successfully implemented and has been supported by a small portion of data showing tsunami affected zones at the Kuta village of Badung district and Sanur village in the city of Denpasar. The red zone indicates that the location is a dangerous area of the tsunami and is generally located on the coastal edge. while the yellow color indicates somewhat dangerous areas within the tsunami zone. while the rest is a safe area. For assembly point can be added with different legend and icon. The determination of assembly point is very dependent on the BPBD of each district. Figure 6 (a) (top) shows an example of an app that is visible from the end user side, whereas Figure 6 (b) (buttom) shows applications that are visible from the authoritative user side.

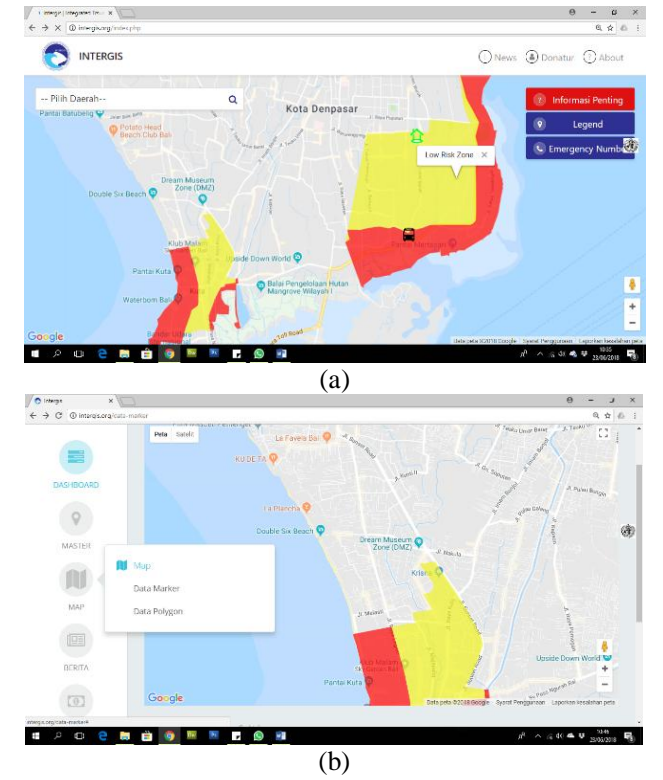

Fig. 6. Application apearance on authoritative (a) user side (top) and (b) end-user side (buttom)

\section{CONCLUSION AND FUTURE WORKS}

INTERGIS is develop using common information system development life cycle that has few general steps, which are planning, analysis, design, and implementation. This application has been successfully developed and tested with data obtained from Badung and Denpasar. the next step is to conduct a survey to map the tsunami affected areas on the coast in other districts. While from the side of the system, the development of Android-based applications will be done after getting the authorization of web service utilization of the Indonesian Tsunami Early Warning System owned by BMKG.

\section{ACKNOWLEDGMENT}

The authors would like to express the great thank to Directorate General for Research strengthening and Development, Ministry of Research, Technology and Higher Education, Republic of Indonesia as the sponsor of this research through the scheme of fundamental prime university research grants.

\section{REFERENCES}

1. U. Kadri, "Tsunami mitigation by resonant triad interaction with acoustic-gravity waves," Heliyon, vol. 3, no. 1, p. e00234, 2017.

2. R. A. Hadiguna, I. Kamil, A. Delati, and R. Reed, "Implementing a web-based decision support system for disaster logistics: A case study of an evacuation location assessment for Indonesia," Int. J. Disaster Risk Reduct., vol. 9, pp. 38-47, 2014.

3. S. K. Chaturvedi, P. K. Srivastava, and U. Guven, "A Brief Review on Tsunami Early Warning Detection using BPR Approach and Post Analysis by SAR Satellite Dataset," J. Ocean Eng. Sci., no. 2017, 2017.

4. S. Sreelal, S. Jose, B. Varghese, M. N. Suma, R. Sumathi, M. Lakshminarayana, and M. M. Nayak, "Data acquisition and processing at ocean bottom for a Tsunami warning system," Measurement, vol. 47, pp. 475-482, 2014.

5. C. Cecioni, G. Bellotti, A. Romano, A. Abdolali, P. Sammarco, and L. Franco, "Tsunami early warning system based on real-time measurements of hydro-acoustic waves," Procedia Eng., vol. 70, pp. 311-320, 2014

6. S. C. Lin, T. R. Wu, E. Yen, H. Y. Chen, J. Hsu, Y. L. Tsai, C. J. Lee, and P. L. F. Liu, "Development of a tsunami early warning system for the South China Sea," Ocean Eng., vol. 100, pp. 1-18, 2015.

7. R. Santos, D. Mosse, T. Znati, and L. Comfort, "Design and implementation of a Witness Unit for opportunistic routing in tsunami alert scenarios," Saf. Sci., vol. 90, pp. 75-83, 2016.

8. A. T. Chatfield, H. J. J. Scholl, and U. Brajawidagda, "Tsunami early warnings via Twitter in government: Net-savvy citizens' co-production of time-critical public information services," Gov. Inf. Q., vol. 30, no. 4, pp. 377-386, 2013.

9. Y. Wang, W. Zhang, B. A. Engel, H. Peng, L. Theller, Y. Shi, and S. Hu, "A fast mobile early warning system for water quality emergency risk in ungauged river basins," Environ. Model. Softw., vol. 73, pp. 76-89, 2015 .

10. G. Badung, Tsunami Evacuation Plan for Kelurahan Kuta, Bali, Firs Editi. Badung: District Goverment of Badung, 2010.

11. G. P. W. G. of S. Denpasar), Tsunami Evacuation Plan for Sanur, Bali, First Edit. Denpasar: District Goverment of Denpasar, 2010.

12. NEAMTIC, A guide to Tsunamis for Hotels, IOC Manual., no. 6 Jakarta: Jakarta Tsunami Information Center UNESCO/IOC, 2009.

13. M. P. Mahoney, C. J. Trisler, and M. Hornick, Vertical Evacuation from Tsunamis: A Guide for Community Officials, Firs Editi., no. June. California: APPLIEN TECHNOLOGY COUNCIL, 2009.

14. F. Ashar, D. Amaratunga, and R. Haigh, "The Analysis of Tsunami Vertical Shelter in Padang City," Procedia Econ. Financ., vol. 18, no. September, pp. 916-923, 2014.

15. R. S. Oktari, K. Munadi, and M. Ridha, "Effectiveness of Dissemination and Communication Element of Tsunami Early Warning System in Aceh," Procedia Econ. Financ., vol. 18, no. September, pp. 136-142, 2014.

16. M. Sättele, M. Bründl, and D. Straub, "Reliability and effectiveness of early warning systems for natural hazards: concept and application to debris flow warning," Reliab. Eng. Syst. Saf., vol. 142, pp. 192-202, 2015.

17. J. Dean and S. Ghemawat, "MapReduce : Simplified Data Processing on Large Clusters," Commun. ACM, vol. 51, no. 1, pp. 1-13, 2008.

18. C. Doukas, T. Pliakas, and I. Maglogiannis, "Mobile healthcare information management utilizing Cloud Computing and Android OS," 2010 Annu. Int. Conf. IEEE Eng. Med. Biol. Soc. EMBC'10, pp. 1037-1040, 2010.

19. W. Yong-qing, L. Pei-de, and L. Yu-guo, "Design and Implementation of the Network Information Filtering System (NIFS).” pp. 1-6. 